Огляди літератури, оригінальні дослідження, погляд на проблему, випадок з практики, короткі повідомлення УдК 615.272.03:[616.36-004.4-06+616.12-008.331.1

DOI 10.11603/1811-2471.2020.v.i2.11188

\title{
ЕФЕКТИВНІСТЬ ЗАСТОСУВАННЯ АТОРВАСТАТИНУ ПРИ ПОЄДНАННІ АЛКОГОЛЬНОЇ ХВОРОБИ ПЕЧІНКИ ТА АРТЕРІАЛЬНОЇ ГІПЕРТЕНЗІЇ
}

\author{
๑В. Є. Молодцов, О. І. Федів, Г. Я. Ступницька \\ ВДНз України «Буковинський державний медичний університет» МОЗ України
}

РЕЗЮМЕ. Останнім часом зросла кількість повідомлень щодо перспективності використання статинів при захворюваннях печінки. Завдяки низькій токсичності та високому рівню безпеки в клінічній практиці найчастіше використовується аторвастатин, у зв'язку з чим доцільним $\epsilon$ дослідження результатів його застосування у хворих на алкогольну хворобу печінки (АХП) за її поєднання з артеріальною гіпертензією (АГ).

Мета - вивчити ефективність застосування аторвастатину у комплексній терапії АХП, поєднаної із АГ, шляхом визначення у крові показників функціонального стану ендотелію, системного запалення, оксидативного стресу, ліпідного та вуглеводного обмінів.

Матеріал і методи. В дослідженні взяли участь 62 хворих на алкогольну хворобу печінки. Усіх обстежених було поділено на дві групи. До першої (контрольної) групи увійшли 11 хворих на хронічний алкогольний гепатит (ХАГ) та 20 хворих на алкогольний цироз печінки (АЦП), яким проводилося загальноприйняте лікування. Другу (основну групу) склали 11 пацієнтів із ХАГ та 20 пацієнтів з АЦП, які на фоні традиційного лікування отримували аторвастатин (по 20 мг 1 раз на добу впродовж 3 місяців).

Визначали вміст у сироватці крові стабільних метаболітів монооксиду нітрогену (нітритів/нітратів), ендотеліну-1, молекул міжклітинної адгезії-1 (ICAM-1), С-реактивного білка, фактора некрозу пухлин- $\alpha$, трансформувального фактора росту- $\beta 1$, інтерлейкіну-10, 8-ізопростану та церулоплазміну. Досліджували також ліпідний спектр крові та деякі показники вуглеводного обміну.

Результати. У хворих на ХАГ та АЦП, поєднані з АГ, під впливом аторвастатину спостерігалося зниження рівня в сироватці крові ендотеліну-1, нітратів/нітритів, ICAM-1, С-реактивного білка, фактора некрозу пухлин- $\alpha$, інтерлейкіну-10, трансформувального фактора росту- $\beta_{1}$, 8-ізопростану, церулоплазміну, загального холестеролу, холестеролу ліпопротеїдів низької щільності, тригліцеролів за одночасного зростання вмісту холестеролу ліпопротеїдів високої щільності.

Висновок. Застосування аторвастатину у комплексному лікуванні хворих на алкогольну хворобу печінки (хронічний алкогольний гепатит та алкогольний цироз печінки), поєднану з артеріальною гіпертензією, приводить до покращання функціонального стану ендотелію, зниження інтенсивності системного запалення та оксидативного стресу на тлі зменшення проявів дисліпопротеїнемії.

КлючОВІ слОВА: алкогольна хвороба печінки; гіпертензія; ендотелій; запалення; оксидативний стрес; аторвастатин.

Вступ. Численні дослідження показали, що, окрім впливу на сироватковий рівень ліпідів, статинам властиві плейотропні ефекти, які зумовлюють їх застосування не тільки при хворобах серця і судин, а й за гострих уражень нирок, нефропатії, панкреатиту, хронічного обструктивного захворювання легень, венозної тромбоемболії, деменції, когнітивної та еректильної дисфункцій, онкопатології, системного червоного вовчака, тяжкого сепсису та при інших захворюваннях [1-3]. Останнім часом зросла кількість повідомлень щодо перспективності їх використання при захворюваннях печінки [4-6]. Відомо також про різноманітні побічні ефекти статинів (виникнення міозитів, рабдоміолізу, катаракти, збільшення ризику розвитку цукрового діабету, дозозалежне зростання активності печінкових ферментів тощо).

Завдяки низькій токсичності та високому рівню безпеки в клінічній практиці найчастіше застосову$\epsilon$ ться аторвастатин [7]. Тому доцільним $\epsilon$ вивчення його ефективності щодо корекції ендотеліальної дисфункції, системного запалення, метаболічних порушень у хворих на хронічний алкогольний гепатит (ХАГ) та алкогольний цироз печінки (АЦП), зокрема за їх поєднання з артеріальною гіпертензією.

Мета - вивчити ефективність застосування аторвастатину у комплексній терапії алкогольної хвороби печінки (АХП), поєднаної із артеріальною гіпертензією (АГ), шляхом визначення у крові показників функціонального стану ендотелію, системного запалення, оксидативного стресу, ліпідного та вуглеводного обмінів.

Матеріал і методи дослідження. Обстежено 62 хворих із встановленим діагнозом алкогольної хвороби печінки (АХП): 22 хворих на ХАГ у поєднанні з артеріальною гіпертензією та 40 хворих на АЦП у поєднанні з артеріальною гіпертензією. Групу порівняння склала 21 практично здорова особа (ПЗО).

Діагноз АХП встановлювали на підставі анамнестичних, клінічних, лабораторних (біохімічних, серологічних, імунологічних) даних, визначення сироваткових маркерів вірусних гепатитів В і С, ре- 
Огляди літератури, оригінальні дослідження, погляд на проблему, випадок з практики, короткі повідомлення зультатів ультразвукового та морфологічного досліджень печінки. Для розпізнавання прихованої алкогольної залежності та для виявлення соматичних еквівалентів хронічної алкогольної інтоксикації була використана «сітка LeGo».

Діагноз есенціальної артеріальної гіпертензії (АГ) встановлювали на підставі настанови Європейського кардіологічного товариства (2013) та вітчизняного «Уніфікованого клінічного протоколу екстреної, первинної, вторинної та третинної (високоспеціалізованої) медичної допомоги: Артеріальна гіпертензія» (Наказ МОЗ України № 384 від 24.05.2012 року).

Усі хворі за випадковою ознакою були поділені на дві групи. До першої (контрольної) групи увійшли 11 хворих на ХАГ та 20 хворих на АЦП, яким проводилося загальноприйняте лікування (гепатопротектори, ліпотрорпні, спазмолітичні препарати, аскорбінова кислота, вітаміни групи В, пробіотики, за необхідності - інфузійна терапія, сечогінні препарати). Другу (основну групу) склали 11 пацієнтів із ХАГ та 20 пацієнтів з АЦП, які на фоні традиційного лікування отримували аторвастатин (по 20 мг 1 раз на добу впродовж 3 місяців).

Визначали вміст у сироватці крові С-реактивного білка (СРБ), фактора некрозу пухлин- $\alpha$ (ФНП $\alpha)$,

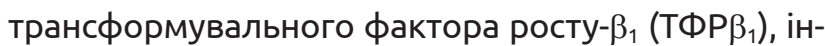
терлейкіну-10 (ІЛ-10), 8-ізопростану - за допомогою імуноферментного аналізу. Функціональний стан ендотелію оцінювали за вмістом у крові стабільних метаболітів монооксиду нітрогену (нітритів/нітратів), ендотеліну-1 (ЕТ-1), молекул міжклітинної адгезії-1 (ICAM-1). Ліпідний спектр крові вивчали за вмістом загального холестеролу (3Х), тригліцеролів (ТГ), холестеролу ліпопротеїдів низької щільності (ХС ЛПНЩ) та холестеролу ліпопротеїдів високої щільності (ХС ЛПВЩ). Вуглеводний обмін оцінювали за рівнем глікемії натще та вмістом у крові глікозильованого гемоглобіну $\left(\mathrm{HbA}_{1 \mathrm{c}}\right)$.

Статистичну обробку отриманих даних проводили за допомогою програми BioStat, Version 2009 for Windows (з6. 5.8.4.3 @2010 AnalystSoft Inc.). Оцінку достовірності відмінностей проводили із застосуванням непараметричного методу за U-критерієм Уїлкоксона. Відмінності вважали статистично значимими при $\mathrm{p}<0,05$.

Результати й обговорення. При аналізі показників функціонального стану ендотелію (табл. 1) встановили, що за призначення аторвастатину хворим на ХАГ з АГ спостерігалось достовірне зменшення вмісту ЕT-1 у сироватці крові на 12,0 \% від вихідного рівня.

Таблиця 1. Показники функціонального стану ендотелію, системного запалення та оксидативного стресу у хворих на хронічний алкогольний гепатит, поєднаний із артеріальною гіпертензією, в динаміці лікування аторвастатином

\begin{tabular}{|c|c|c|c|c|c|}
\hline \multirow[t]{2}{*}{ Показники } & \multirow{2}{*}{$\begin{array}{c}\text { Практично здорові } \\
\text { (контрольна група) } \\
n=21\end{array}$} & \multicolumn{2}{|c|}{$\begin{array}{c}\text { Хворі на ХАГ, поєднаний із АГ } \\
\text { (контрольна група) } \\
n=11\end{array}$} & \multicolumn{2}{|c|}{$\begin{array}{c}\text { Хворі на ХАГ, поєднаний із АГ } \\
\text { (основна група) } \\
n=11\end{array}$} \\
\hline & & до лікування & після лікування & до лікування & після лікування \\
\hline $\begin{array}{l}\text { Ендотелін-1, } \\
\text { пмоль/л }\end{array}$ & $14,24 \pm 0,08$ & $15,4 \pm 0,59$ & $14,94 \pm 0,60$ & $16,58 \pm 0,52$ & $\begin{array}{c}14,59 \pm 0,31 \\
* *\end{array}$ \\
\hline $\begin{array}{l}\text { Загальний оксид } \\
\text { азоту, } \\
\text { мкмоль/л }\end{array}$ & $84,67 \pm 0,43$ & $138,09 \pm 6,41$ & $\begin{array}{c}127,73 \pm 5,83 \\
* / * *\end{array}$ & $146,82 \pm 5,74$ & $\begin{array}{c}116,82 \pm 3,25 \\
* / * *\end{array}$ \\
\hline $\begin{array}{l}\text { ICAM-1, } \\
\text { од/мл }\end{array}$ & $222,52 \pm 5,96$ & $264,37 \pm 2,88$ & $\begin{array}{c}257,24 \pm 2,82 \\
*\end{array}$ & $253,74 \pm 3,47$ & $\begin{array}{c}235,11 \pm 5,13 \\
* * / * * * \\
\end{array}$ \\
\hline $\begin{array}{l}\mathrm{CPБ,} \\
\mathrm{Mr/ת}\end{array}$ & $5,71 \pm 1,40$ & $42,73 \pm 1,98$ & $\begin{array}{c}39,73 \pm 1,91 \\
* / * *\end{array}$ & $44,18 \pm 1,80$ & $\begin{array}{c}35,45 \pm 2,14 \\
* / * *\end{array}$ \\
\hline $\begin{array}{l}\text { ФНП- } \alpha, \\
\text { пг/мл }\end{array}$ & $7,52 \pm 0,06$ & $11,58 \pm 0,40$ & $\begin{array}{c}10,73 \pm 0,40 \\
* / * *\end{array}$ & $11,65 \pm 0,39$ & $\begin{array}{c}9,60 \pm 0,34 \\
* / * *\end{array}$ \\
\hline $\begin{array}{l}\text { ТФР } \beta_{1}, \\
\text { пг/Мл }\end{array}$ & $32,11 \pm 0,52$ & $38,06 \pm 0,38$ & $\begin{array}{c}37,9 \pm 0,41 \\
* \\
\end{array}$ & $35,34 \pm 0,85$ & $\begin{array}{c}32,05 \pm 0,67 \\
* * / * * *\end{array}$ \\
\hline $\begin{array}{l}\text { ІЛ-10, } \\
\text { пг/мЛ }\end{array}$ & $7,36 \pm 0,23$ & $12,96 \pm 0,29$ & $\begin{array}{c}11,05 \pm 0,29 \\
* / * *\end{array}$ & $12,54 \pm 0,39$ & $\begin{array}{c}9,69 \pm 0,36 \\
* / * * / * * *\end{array}$ \\
\hline $\begin{array}{l}\text { 8-ізопростан, } \\
\text { нг/мл }\end{array}$ & $1,30 \pm 0,02$ & $1,81 \pm 0,07$ & $\begin{array}{c}1,65 \pm 0,08 \\
*\end{array}$ & $1,61 \pm 0,07$ & $\begin{array}{c}1,28 \pm 0,03 \\
* * / * * * \\
\end{array}$ \\
\hline $\begin{array}{l}\text { Церулоплазмін, } \\
\text { мг/л }\end{array}$ & $0,95 \pm 0,01$ & $1,92 \pm 0,10$ & $\begin{array}{c}1,80 \pm 0,06 \\
* / * *\end{array}$ & $2,11 \pm 0,18$ & $\begin{array}{c}1,63 \pm 0,12 \\
* / * *\end{array}$ \\
\hline
\end{tabular}

Примітка. * - відмінності достовірні у порівнянні з групою практично здорових осіб; ** - відмінності достовірні у порівнянні з показниками до лікування; *** - відмінності достовірні у порівнянні між контрольною та основною групами після лікування. 
Огляди літератури, оригінальні дослідження, погляд на проблему, випадок з практики, короткі повідомлення

Рівень нітратів/нітритів у даній групі пацієнтів знижувався в динаміці лікування на 20,4 \% і він був на 27,5 \% вищим, ніж у ПЗО. У контрольній групі цей показник покращувався лише на 7,5 \% і перевищував контроль на 33,7 \%. Вміст ІСАМ-1 в основній групі достовірно знижувався після лікування і був на 8,6 \% нижчим, порівняно із контрольною групою пацієнтів, та достовірно не відрізнявся від ПЗО.
У хворих на АЦП з АГ спостерігалися подібні зміни: рівень ЕT-1, нітратів/нітритів та ICAM-1 в основній групі знижувався в динаміці лікування на 13,4 \%, 18,2 та 10,1 \% відповідно (табл. 2). У групі хворих, які не отримували аторвастатин, спостерігалася лише тенденція до покращання зазначених показників і наприкінці лікування вони залишалися достовірно вищими за контроль.

Таблиця 2. Показники функціонального стану ендотелію та системного запалення у хворих на цироз печінки, поєднаний із артеріальною гіпертензією, в динаміці лікування аторвастатином

\begin{tabular}{|c|c|c|c|c|c|}
\hline \multirow[t]{2}{*}{ Показники } & \multirow{2}{*}{$\begin{array}{c}\text { Практично здорові } \\
\text { (контрольна група) } \\
\text { n=21 }\end{array}$} & \multicolumn{2}{|c|}{$\begin{array}{c}\text { Хворі на АЦП, поєднаний із АГ } \\
\text { (контрольна група) } \\
n=20\end{array}$} & \multicolumn{2}{|c|}{$\begin{array}{c}\text { Хворі на АЦП, поєднаний із АГ } \\
\text { (основна група) } \\
\text { n=20 }\end{array}$} \\
\hline & & до лікування & після лікування & до лікування & після лікування \\
\hline $\begin{array}{l}\text { Ендотелін-1, } \\
\text { пмоль/л }\end{array}$ & $14,24 \pm 0,08$ & $19,41 \pm 0,31$ & $\begin{array}{c}18,63 \pm 0,33 \\
* / * *\end{array}$ & $19,81 \pm 0,65$ & $\begin{array}{c}17,15 \pm 0,50 \\
* / * *\end{array}$ \\
\hline $\begin{array}{l}\text { Загальний оксид } \\
\text { азоту, } \\
\text { мкмоль/л }\end{array}$ & $84,67 \pm 0,43$ & $93,00 \pm 3,41$ & $\begin{array}{c}99,90 \pm 3,45 \\
*\end{array}$ & $121,90 \pm 8,38$ & $\begin{array}{c}99,75 \pm 3,78 \\
* / * *\end{array}$ \\
\hline $\begin{array}{l}\text { ICAM-1, } \\
\text { од/мл }\end{array}$ & $222,52 \pm 5,96$ & $291,09 \pm 3,20$ & $\begin{array}{c}283,96 \pm 3,32 \\
*\end{array}$ & $282,25 \pm 2,32$ & $\begin{array}{c}253,64 \pm 2,55 \\
* / * *\end{array}$ \\
\hline $\begin{array}{l}\text { СРБ, } \\
\text { Мг/л }\end{array}$ & $5,71 \pm 1,40$ & $24,65 \pm 1,10$ & $\begin{array}{c}22,90 \pm 1,37 \\
*\end{array}$ & $28,75 \pm 2,51$ & $\begin{array}{c}21,80 \pm 2,29 \\
* / * *\end{array}$ \\
\hline $\begin{array}{l}\text { ФНП- } \alpha, \\
\text { пг/мл } \\
\end{array}$ & $7,52 \pm 0,06$ & $8,75 \pm 0,24$ & $\begin{array}{c}8,74 \pm 0,24 \\
* \\
\end{array}$ & $8,79 \pm 0,19$ & $\begin{array}{c}7,93 \pm 0,14 \\
* / * * / * * * \\
\end{array}$ \\
\hline $\begin{array}{l}\text { ТФР } \beta_{1} \\
\text { пг/мл }\end{array}$ & $32,11 \pm 0,52$ & $42,67 \pm 0,41$ & $\begin{array}{c}41,42 \pm 0,43 \\
* \\
\end{array}$ & $38,58 \pm 0,92$ & $\begin{array}{c}34,65 \pm 0,82 \\
* / * * / * * * \\
\end{array}$ \\
\hline $\begin{array}{l}\text { ІЛ-10, } \\
\text { пг/мл }\end{array}$ & $7,36 \pm 0,23$ & $8,99 \pm 0,19$ & $\begin{array}{c}8,48 \pm 0,18 \\
*\end{array}$ & $8,77 \pm 0,28$ & $\begin{array}{c}7,71 \pm 0,17 \\
* * * * * * \\
\end{array}$ \\
\hline $\begin{array}{l}\text { 8-ізопростан, } \\
\text { нг/мл }\end{array}$ & $1,30 \pm 0,02$ & $2,18 \pm 0,03$ & $\begin{array}{c}1,87 \pm 0,09 \\
* / * *\end{array}$ & $1,84 \pm 0,09$ & $\begin{array}{c}1,50 \pm 0,07 \\
* / * * / * * *\end{array}$ \\
\hline $\begin{array}{l}\text { Церулоплазмін, } \\
\text { мг/л }\end{array}$ & $0,95 \pm 0,01$ & $1,84 \pm 0,06$ & $\begin{array}{c}1,76 \pm 0,05 \\
*\end{array}$ & $1,85 \pm 0,07$ & $\begin{array}{c}1,49 \pm 0,06 \\
* / * * / * * *\end{array}$ \\
\hline
\end{tabular}

Примітка. * - відмінності достовірні у порівнянні з групою практично здорових осіб; ** - відмінності достовірні у порівнянні з показниками до лікування; *** - відмінності достовірні у порівнянні між контрольною та основною групами після лікування.

Отримані результати дослідження демонструють покращання функціонального стану ендотелію при застосуванні аторвастатину у хворих із поєднанням алкогольного ураження печінки та $А Г$, що, можливо, зумовлено його позитивним впливом на регуляцію продукції монооксиду нітрогену, у тому числі через зменшення системного запалення та оксидативного стресу. Експериментальними та клінічними дослідженнями продемонстровано зниження інтенсивності оксидативного стресу та системного запалення при застосуванні статинів [7].

Оцінка динаміки змін показників системного запалення в процесі лікування аторвастатином (табл. 1) показала, що у хворих на ХАГ вміст СРБ знижувався (на 19,8 \% від вихідного рівня), проте залишався досить високим порівняно із ПЗО (в 6,2 раза). У хворих контрольної групи цей показ- ник знижувався лише на 7,0 \% і перевищував контроль у 7 разів. Вміст ФНП- $\alpha$ у сироватці крові після лікування знижувався на 27,7 \% в основній групі, на 7,3 \% - в контрольній групі, проте залишався достовірно вищим за такий рівень у ПЗО на $17,7 \%$ та 42,7 \% відповідно. Водночас рівень ТФР $\beta_{1}$ у хворих контрольної групи достовірно не змінювався (залишався вищим за контроль на 18,0 \%). За використання аторвастатину цей показник знижувався на 9,3 \% ( $<<0,05)$, досягаючи нормального рівня, і був нижчим на 15,4 \% порівняно із контрольною групою. Рівень ІЛ-10 у хворих основної групи наприкінці лікування достовірно знижувався на $22,7 \%$ та був нижчим на 12,3 \% порівняно із контрольною групою.

У хворих на АЦП з АГ використання аторвастатину приводило до достовірного зниження усіх показників наприкінці лікування (СРБ - на 
Огляди літератури, оригінальні дослідження, погляд на проблему, випадок з практики, короткі повідомлення $24,2 \%$, ФНП- $\alpha$ - на 9,8\%, ТФР $\beta_{1}$ - на 10,2\% та ІЛ-10 на $12,1 \%)$. Водночас показники вмісту ФНП $\alpha$, ТФР $\beta_{1}$ та ІЛ-10 були нижчими на 9,3\%, 16,3\% та 9,1\% відповідно, порівняно із контрольною групою пацієнтів (див. табл. 2). За призначення стандартної базової терапії без аторвастатину достовірних змін у динаміці лікування не спостерігалось.

Показники про- та антиоксидантної систем крові у пацієнтів з ХАГ та АГ основної групи після лікування характеризувалися достовірним зниженням рівня 8-ізопростану (на 18,5 \%) та вмісту церулоплазміну (на 19,5 \%) у сироватці крові та порівняно із контрольною групою хворих були на 9,8 \% та 15,3 \% відповідно нижчими (див. табл. 1). У хворих на АЦП з АГ, які не отримували аторвастатин, спостерігалось лише достовірне зниження вмісту 8-ізопростану (на 14,2 \%), а рівень церулоплазміну залишався істотно вищим (в 1,9 раза), порівняно із ПЗО (див. табл. 2).

Отже, використання аторвастатину у хворих на алкогольну хворобу печінки, поєднану із АГ, приводило до зниження інтенсивності запалення та оксидативного стресу через зменшення продукції СРБ, прозапальних цитокінів, 8-ізопростану і церулоплазміну.

Найістотніший вплив аторвастатину виявлений при дослідженні деяких показників ліпідного спектра крові (табл. 3). Зокрема, у хворих на ХАГ 3 АГ встановлено достовірне зниження вмісту 3 Ха ХС ЛПнЩ (на 12,9 \% та 24,4 \% відповідно). При цьому зазначені показники після лікування були на $12,5 \%$ та $27,6 \%$ нижчими $(p<0,05)$, порівняно із контрольною групою пацієнтів, у яких достовірних змін у динаміці лікування не спостерігалося. Рівень ХС ЛПВЩ у групі пацієнтів, до комплексу лікування яких додавали аторвастатин, достовірно зростав (на 28,7\%), перевищуючи (на 49,4 \%) відповідний показник у хворих, яким аторвастатин не призначався. Концентрація ТГ також достовірно знижувалась наприкінці спостереження у основній групі (на 26,2 \%), вірогідно відрізняючись від показників після лікування в контрольній групі.

Таблиця 3. Показники ліпідного та вуглеводного обміну у хворих на хронічний алкогольний гепатит, поєднаний із артеріальною гіпертензією, в динаміці лікування аторвастатином

\begin{tabular}{|c|c|c|c|c|c|}
\hline \multirow[t]{2}{*}{ Показники } & \multirow{2}{*}{$\begin{array}{c}\text { Практично здорові } \\
\text { (контрольна група) } \\
n=21\end{array}$} & \multicolumn{2}{|c|}{$\begin{array}{c}\text { Хворі на ХАГ, поєднаний із АГ } \\
\text { (контрольна група) } \\
\text { n=20 }\end{array}$} & \multicolumn{2}{|c|}{$\begin{array}{c}\text { Хворі на ХАГ, поєднаний із АГ } \\
\text { (основна група) } \\
\text { n=20 }\end{array}$} \\
\hline & & до лікування & після лікування & до лікування & після лікування \\
\hline $\begin{array}{l}\text { Загальний холестерин, } \\
\text { ммоль/л }\end{array}$ & $4,35 \pm 0,14$ & $6,23 \pm 0,17$ & $\begin{array}{c}6,24 \pm 0,19 \\
* \\
\end{array}$ & $6,27 \pm 0,20$ & $\begin{array}{l}5,46 \pm 0,1 \\
* / * * / * * *\end{array}$ \\
\hline $\begin{array}{l}\text { ХС лПНЩ, } \\
\text { ммоль/л }\end{array}$ & $2,46 \pm 0,09$ & $3,89 \pm 0,22$ & $\begin{array}{c}3,81 \pm 0,21 \\
*\end{array}$ & $3,65 \pm 0,24$ & $\begin{array}{c}2,76 \pm 0,18 \\
* / * * / * * *\end{array}$ \\
\hline $\begin{array}{l}\text { ХС лПВЩ, } \\
\text { ммоль/л }\end{array}$ & $1,46 \pm 0,07$ & $0,86 \pm 0,06$ & $\begin{array}{c}0,81 \pm 0,04 \\
*\end{array}$ & $0,94 \pm 0,06$ & $\begin{array}{c}1,21 \pm 0,04 \\
* / * * / * * *\end{array}$ \\
\hline $\begin{array}{l}\text { Тригліцериди, } \\
\text { ммоль/л }\end{array}$ & $1,45 \pm 0,06$ & $2,98 \pm 0,19$ & $\begin{array}{c}2,82 \pm 0,18 \\
*\end{array}$ & $2,86 \pm 0,16$ & $\begin{array}{c}2,11 \pm 0,09 \\
* / * * / * * *\end{array}$ \\
\hline $\begin{array}{l}\text { Глюкоза, } \\
\text { ммоль/л }\end{array}$ & $4,49 \pm 0,07$ & $5,13 \pm 0,26$ & $5,12 \pm 0,25$ & $5,07 \pm 0,18$ & $4,95 \pm 0,17$ \\
\hline $\begin{array}{l}\mathrm{HbA}_{1 \mathrm{C}^{\prime}} \\
\%\end{array}$ & $4,27 \pm 0,12$ & $5,74 \pm 0,31$ & $\begin{array}{c}5,65 \pm 0,26 \\
*\end{array}$ & $4,57 \pm 0,22$ & $\begin{array}{c}4,50 \pm 0,14 \\
* * *\end{array}$ \\
\hline
\end{tabular}

Примітка. * - відмінності достовірні у порівнянні з групою практично здорових осіб; ** - відмінності достовірні у порівнянні з показниками до лікування; *** - відмінності достовірні у порівнянні між контрольною та основною групами після лікування.

У хворих на АЦП з АГ виявлені аналогічні зміни. У хворих контрольної групи показники залишались достовірно гіршими, порівняно з ПЗО. В динаміці лікування тільки рівень ТГ достовірно знижувався на 6,8 \% (табл. 4). У пацієнтів, які отримували аторвастатин, в динаміці лікування спостерігалося достовірне зниження вмісту ЗХ, ТГ та ХС лПнЩ (на 10,4 \%, 23,6 \% та 30,6 \% відповідно). Водночас ці показники були нижчими, порівняно з контрольною групою хворих (на 9,6 \%, 15,3 \% та 24,8 \% відповідно). Крім того, у пацієнтів основної групи на 25,8 \% збільшився рівень ХС лПВЩ, пе- ревищуючи на 27,3 \% відповідний показник у контрольній групі пацієнтів, у яких достовірних змін у динаміці лікування не спостерігалось.

Щодо змін показників вуглеводного обміну (див. табл. 3, 4) варто зазначити, що в обох групах пацієнтів достовірних відмінностей вмісту глюкози та $\mathrm{HbA}_{1 \mathrm{c}}$ в процесі лікування не спостерігалось.

Висновки. Застосування аторвастатину у комплексному лікуванні хворих на алкогольну хворобу печінки (хронічний алкогольний гепатит та алкогольний цироз печінки), поєднану із артеріальною гіпертензією, приводить до покращання функціо- 
Огляди літератури, оригінальні дослідження, погляд на проблему, випадок з практики, короткі повідомлення Таблиця 4. Показники ліпідного та вуглеводного обміну у хворих на цироз печінки, поєднаний із артеріальною гіпертензією, в динаміці лікування аторвастатином

\begin{tabular}{|c|c|c|c|c|c|}
\hline \multirow[t]{2}{*}{ Показники } & \multirow{2}{*}{$\begin{array}{c}\text { Практично здорові } \\
\text { (контрольна група) } \\
n=21\end{array}$} & \multicolumn{2}{|c|}{$\begin{array}{c}\text { Хворі на АЦП, поєднаний із АГ } \\
\text { (контрольна група) } \\
n=20\end{array}$} & \multicolumn{2}{|c|}{$\begin{array}{c}\text { Хворі на АЦП, поєднаний із АГ } \\
\text { (основна група) } \\
n=20\end{array}$} \\
\hline & & до лікування & після лікування & до лікування & після лікування \\
\hline $\begin{array}{l}\text { Загальний холестерин, } \\
\text { ммоль/л }\end{array}$ & $4,35 \pm 0,14$ & $5,75 \pm 0,14$ & $\begin{array}{c}5,65 \pm 0,12 \\
*\end{array}$ & $5,70 \pm 0,17$ & $\begin{array}{c}5,11 \pm 0,14 \\
* / * * / * * *\end{array}$ \\
\hline $\begin{array}{l}\text { ХС лПНЩ, } \\
\text { ммоль/л }\end{array}$ & $2,46 \pm 0,09$ & $3,48 \pm 0,10$ & $\begin{array}{c}3,33 \pm 0,09 \\
* \\
\end{array}$ & $3,69 \pm 0,10$ & $\begin{array}{c}2,82 \pm 0,07 \\
* / * * / * * *\end{array}$ \\
\hline $\begin{array}{l}\text { ХС лПВЩ, } \\
\text { ммоль/л }\end{array}$ & $1,46 \pm 0,07$ & $0,86 \pm 0,06$ & $\begin{array}{c}0,88 \pm 0,05 \\
*\end{array}$ & $0,89 \pm 0,04$ & $\begin{array}{c}1,12 \pm 0,05 \\
* / * * / * * *\end{array}$ \\
\hline $\begin{array}{l}\text { Тригліцериди, } \\
\text { ммоль/л }\end{array}$ & $1,45 \pm 0,06$ & $2,81 \pm 0,05$ & $\begin{array}{c}2,62 \pm 0,05 \\
* / * *\end{array}$ & $2,84 \pm 0,10$ & $\begin{array}{c}1,97 \pm 0,07 \\
* / * * / * * *\end{array}$ \\
\hline $\begin{array}{l}\text { Глюкоза, } \\
\text { ммоль/л }\end{array}$ & $4,49 \pm 0,07$ & $4,66 \pm 0,13$ & $4,70 \pm 0,10$ & $4,90 \pm 0,14$ & $4,63 \pm 0,12$ \\
\hline $\begin{array}{l}\mathrm{HbA}_{1 \mathrm{c}} \\
\%\end{array}$ & $4,27 \pm 0,12$ & $5,40 \pm 0,08$ & $\begin{array}{c}5,44 \pm 0,11 \\
*\end{array}$ & $4,81 \pm 0,12$ & $\begin{array}{c}4,63 \pm 0,09 \\
* * *\end{array}$ \\
\hline
\end{tabular}

Примітка * - відмінності достовірні у порівнянні з групою практично здорових осіб; ** - відмінності достовірні у порівнянні з показниками до лікування; *** - відмінності достовірні у порівнянні між контрольною та основною групами після лікування.

нального стану ендотелію (зниження рівня ендотеліну-1, нітратів/нітритів та ICAM-1); зниження інтенсивності системного запалення (підтверджувалося зниженням рівня С-реактивного білка, фактора некрозу пухлин- $\alpha$, інтерлейкіну-10, трансформувального фактора росту $\beta_{1}$ ) та оксидативного стресу (супроводжувалося зменшенням вмісту 8-ізопростану та церулоплазміну в сироватці крові) на тлі зменшення проявів дисліпопротеїнемії (зниження рівня загального холестеролу, холесте-

\section{ЛITЕРАТУРА}

1. Use of statins in patients with chronic liver disease and cirrhosis: Current views and prospects / J. I. Vargas, M. Arrese, V. H. Shah, J. P. Arab // Curr. Gastroenterol Rep. - 2017. - Vol. 19, No. 9. - P. 43.

2. Bosch J. Cirrhosis as new indication for statins / J. Bosch, J. Gracia-Sancho, J. G. Abraldes // Gut. - 2020. Vol. 69, No. 5. - P. 953-962.

3. Pleiotropic effects of statins in the diseases of the liver / M. Janicko, S. Drazilova, D. Pella [et al.] // World J. Gastroenterol. - 2016. - Vol. 22, No. 27. - P. 6201-6213.

4. Souk K. The safety and benefit of statins in liver cirrhosis: A review / K. Souk, M. Al-Badri, S. T. Azar // Exp. Clin. Endocrinol. Diabetes. - 2015. - Vol. 123, No. 10. P. 577-580.

\section{REFERENCES}

1. Vargas, J.I., Arrese, M., Shah, V.H., \& Arab, J.P. (2017). Use of statins in patients with chronic liver disease and cirrhosis: Current views and prospects. Curr. Gastroenterol. Rep., 19 (9), 43. DOI: 10.1007/s11894-017-0584-7.

2. Bosch, J., Gracia-Sancho, J., \& Abraldes, J.G. (2020). Cirrhosis as new indication for statins. Gut.,69 (5), 953-962. DOI: 10.1136/gutjnl-2019-318237. Epub 2020 Mar 5. ролу ліпопротеїдів низької щільності, тригліцеролів за одночасного зростання вмісту холестеролу ліпопротеїдів високої щільності).

Перспективи подальших досліджень. Необхідність удосконалення тактики ведення хворих із поєднанням алкогольної хвороби печінки та артеріальної гіпертензії зумовлює доцільність подальшого порівняльного дослідження ефективності застосування різних статинів при зазначеній патології.

5. Lipophilic statins and risk for hepatocellular carcinoma and death in patients with chronic viral hepatitis: Results from a nationwide Swedish population / T. G. Simon, A. S. Duberg, S. Aleman [et al.] // Ann. Intern. Med. 2019. - Vol. 171, No. 5. - P. 318-327.

6. Current and future pharmacological therapies for managing cirrhosis and its complications / D. Kockerling, R. Nathwani, R. Forlano [et al.] // World J. Gastroenterol. 2019. - Vol. 25, No. 8. - P. 888-908.

7. Atorvastatin for prevention of disease progression and hospitalisation in liver cirrhosis: protocol for a randomised, double-blind, placebo-controlled trial / N. Kimer, H. Grønbæk, R. G. Fred [et al.] // BMJ Open. - 2020. Vol. 10, No. 1. - P. e035284.

3. Janicko, M., Drazilova, S., Pella, D., Fedacko, J., \& Jarcuska, P. (2016). Pleiotropic effects of statins in the diseases of the liver. World J. Gastroenterol., 21; 22 (27), 6201-6213. DOI: 10.3748/wjg.v22.i27.6201.

4. Souk, K., Al-Badri, M., \& Azar, S.T. (2015). The safety and benefit of statins in liver cirrhosis: A review. Exp. Clin. Endocrinol. Diabetes, 123 (10), 577-580. 
Огляди літератури, оригінальні дослідження, погляд на проблему, випадок з практики, короткі повідомлення DOI: 10.1055/s-0035-1564093. Epub 2015 Nov 24. PMID: 26600051 Review.

5. Simon, T.G., Duberg, A.S., Aleman, S., Hagstrom, H., Nguyen, L.H., Khalili, H., Chung, R.T., \& Ludvigsson, J.F. (2019). Lipophilic statins and risk for hepatocellular carcinoma and death in patients with chronic viral hepatitis: Results from a nationwide Swedish population. Ann. Intern. Med., 3; 171 (5), 318-327. DOI: 10.7326/M18-2753. Epub 2019 Aug 20.

6. Kockerling, D., Nathwani, R., Forlano, R., Manousou, P., Mullish, B.H., \& Dhar, A. (2019). Current and future

pharmacological therapies for managing cirrhosis and its complications. World J. Gastroenterol., 25 (8), 888-908. DOI: $10.3748 /$ wjg.v25.i8.888.

7. Kimer, N., Grønbæk, H., Fred, R.G., Hansen, T., Deshmukh, A.S., Mann, M., \& Bendtsen, F. (2020). Atorvastatin for prevention of disease progression and hospitalisation in liver cirrhosis: protocol for a randomised, doubleblind, placebo-controlled trial. BMJ Open, 10 (1), e035284. DOI: 10.1136/bmjopen-2019-035284.

\title{
ЭФФЕКТИВНОСТЬ ПРИМЕНЕНИЯ АТОРВАСТАТИНА ПРИ СОЧЕТАНИИ АЛКОГОЛЬНОЙ БОЛЕЗНИ ПЕЧЕНИ И АРТЕРИАЛЬНОЙ ГИПЕРТЕНЗИИ
}

\author{
ФВ. Е. Молодцов, А. И. Федив, А. Я. Ступницкая
}

ВГУЗ Украины «Буковинский государственный медицинский университет» МОЗ Украины

РЕЗЮМЕ. В последнее время возросло количество сообщений о перспективности использования статинов при заболеваниях печени. Благодаря низкой токсичности и высокому уровню безопасности чаще всего в клинической практике используется аторвастатин, в связи с чем целесообразно исследование результатов его применения у больных алкогольной болезнью печени (АБП) при их сочетании с артериальной гипертензией (АГ).

Цель - изучить эффективность применения аторвастатина в комплексной терапии АБП, сочетанной с АГ, путем определения в крови показателей функционального состояния эндотелия, системного воспаления, оксидативного стресса, липидного и углеводного обменов.

Материал и методы. В исследовании приняли участие 62 больных алкогольной болезнью печени. Все обследованные были поделены на две группы. В первую (контрольную) группу вошли 11 больных хроническим алкогольным гепатитом (ХАГ) и 20 больных алкогольным циррозом печени (АЦП), которым проводилось общепринятое лечение. Вторую (основную группу) составили 11 пациентов с ХАГ и 20 пациентов с АЦП, которые на фоне традиционного лечения получали аторвастатин (по 20 мг 1 раз в сутки в течение 3 месяцев).

Определяли содержание в сыворотке крови стабильных метаболитов оксида азота (нитритов/нитратов), эндотелина-1, молекул межклеточной адгезии-1 (ICAM-1), C-реактивного белка, фактора некроза опухолей- $\alpha$, трансформирующего фактора роста- $\beta_{1}$, интерлейкина-10, 8-изопростана и церулоплазмина. Исследовали также липидный спектр крови и некоторые показатели углеводного обмена.

Результаты. У больных ХАГ и АЦП в сочетании с АГ под влиянием аторвастатина наблюдалось снижение уровня в сыворотке крови эндотелина-1, нитратов/нитритов, ICAM-1, С-реактивного белка, фактора некроза опухолей- $\alpha$,

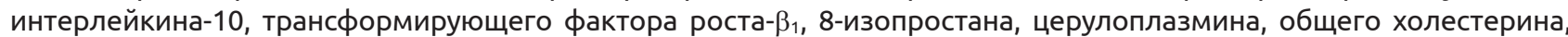
холестерина липопротеидов низкой плотности, триглицерола при одновременном росте содержания холестерина липопротеидов высокой плотности.

Вывод. Применение аторвастатина в комплексном лечении больных алкогольной болезнью печени (хронический алкогольный гепатит и алкогольный цирроз печени), сочетанной с артериальной гипертензией, приводит к улучшению функционального состояния эндотелия, снижению интенсивности системного воспаления и оксидативного стресса на фоне уменьшения проявлений дислипопротеинемии.

КЛючЕВЫЕ СЛОВА: алкогольная болезнь печени; гипертензия; эндотелий; воспаление; оксидативный стресс; аторвастатин.

\section{EFFICACY OF ATORVASTATIN IN THE COMBINATION OF ALCOHOLIC LIVER DISEASE AND HYPERTENSION}

\author{
○V. Ye. Molodtsov, O. I. Fediv, G. Ya. Stupnytska \\ Bukovynian State Medical University
}

SUMMARY. Recently, the number of reports on the prospects for the use of statins in liver disease has increased. Due to its low toxicity and high level of safety, atorvastatin is most commonly used in clinical practice, so it is advisable to study the results of its use in patients with alcoholic liver disease (ALD) in combination with hypertension (AH).

The aim - to study the effectiveness of atorvastatin in the complex therapy of ALD combined with hypertension by determining in the blood indicators of the functional state of the endothelium, systemic inflammation, oxidative stress, lipid and carbohydrate metabolism. 
Огляди літератури, оригінальні дослідження, погляд на проблему, випадок з практики, короткі повідомлення

Material and Methods. The study involved 62 patients with alcoholic liver disease. All subjects were divided into two groups. The first (control) group included 11 patients with chronic alcoholic hepatitis (CAH) and 20 patients with alcoholic liver cirrhosis (AIC), who received conventional treatment. The second (main group) consisted of 11 patients with $\mathrm{CAH}$ and 20 patients with ALC who received atorvastatin ( $20 \mathrm{mg}$ once daily for 3 months) on the background of traditional treatment.

Serum levels of stable metabolites of nitrogen monoxide (nitrites/nitrates), endothelin-1, intercellular adhesion molecules-1 (ICAM-1), C-reactive protein, tumor necrosis factor- $\alpha$, transforming growth factor- $\beta_{1}$, interleukin-10, 8-isoprostane and ceruloplasmin were determined. Blood lipid spectrum and some indicators of carbohydrate metabolism were also studied.

Results. In patients with CAH and ALC combined with hypertension, under the influence of atorvastatin there was a decrease in serum levels of endothelin-1, nitrates/nitrites, ICAM-1, C-reactive protein, tumor necrosis factor- $\alpha$, interleukin-10, transforming growth factor- $\beta_{1}$, 8-isoprostane, ceruloplasmin, total cholesterol, low-density lipoprotein cholesterol, triglycerols with a simultaneous increase in high-density lipoprotein cholesterol.

Conclusion. The use of atorvastatin in the complex treatment of patients with alcoholic liver disease (chronic alcoholic hepatitis and alcoholic liver cirrhosis), combined with hypertension, improves the functional state of the endothelium, reduces the intensity of systemic inflammation and oxidative stress on the background of reduced dyslipoprotein.

KEY WORDS: alcoholic liver disease; hypertension; endothelium; inflammation; oxidative stress; atorvastatin. 